\title{
Antibacterial activity of isothiocyanates from cruciferous vegetables against pathogenic bacteria in olive flounder
}

\author{
$\mathrm{Mi}-\mathrm{Ok} \mathrm{Ko}^{1,2}$, Jeong-Yeon $\mathrm{Ko}^{1,2}$, Mi-Bo Kim ${ }^{2,3}$, Sang-Bin $\mathrm{Lim}^{1,2 *}$ \\ ${ }^{1}$ Department of Food Bioengineering, Jeju National University, Jeju 63243, Korea \\ ${ }^{2}$ Jeju Wellbeing Vegetables RIS System, Jeju National University, Jeju 63243, Korea \\ ${ }^{3}$ Department of Biotechnology, Yonsei University, Seoul 03722, Korea
}

\section{십자화과 채소 유래 isothiocyanates의 넙치 어병세균에 대한 항균활성}

\author{
고미옥 ${ }^{1,2} \cdot$ 고정연 ${ }^{1,2} \cdot$ 김미보 ${ }^{2,3}$. 임상빈 ${ }^{1,2 *}$ \\ ${ }^{1}$ 제주대학교 식품생명공학과, ${ }^{2}$ 제주대학교 제주양채류RIS사업단, ${ }^{3}$ 연세대학교 생명공학과
}

\begin{abstract}
The antimicrobial effects of ten isothiocyanates (ITCs) present in cruciferous vegetables and radish root hydrolysate were investigated against pathogenic bacteria from olive flounder. Minimum inhibitory concentration (MIC) and minimum bactericidal concentration (MBC) were measured against two gram-positive bacterial strains (Streptococcus parauberis, S. iniae) and four gram-negative bacterial strains (Edwardsiella tarda, Vibrio ichthyoenteri, V. harveyi, Photobacterium damselae) by using a broth microdilution technique. The antibacterial activity of ITCs was in the order sulforaphane $>$ sulforaphene $>$ phenylethyl ITC $>$ erucin $>$ benzyl ITC $>$ iberin $>$ I3C $>$ allyl ITC $>$ phenyl ITC $>$ hexyl ITC. The susceptibility of fish pathogens to ITCs was in the order of $V$. harveyi $>E$. tarda $>P$. damselae $>S$. parauberis $>S$. iniae $>V$. ichthyoenteri. Antimicrobial activity (MIC) of radish root hydrolysate was $0.250 \mathrm{mg} / \mathrm{mL}$ against $S$. iniae, $0.438 \mathrm{mg} / \mathrm{mL}$ against $S$. parauberis, and $0.500 \mathrm{mg} / \mathrm{mL}$ against both $E$. tarda and $V$. harveyi. The aliphatic ITCs were potent inhibitors of the growth of fish pathogens, followed by aromatic ITCs and indolyl ITC. The presence of a double bond in the chemical structure of ITCs decreased antibacterial activity, while ITCs with a thiol (-S-) group and a longer carbon chain increased antibacterial activity. These results suggest that ITCs have strong antibacterial activities and may be useful in the prevention of fish pathogens.
\end{abstract}

Key words : isothiocyanates, radish root hydrolysate, antimicrobial activity, fish pathogenic bacteria

\section{서 론}

브로콜리, 양배추, 적채, 콜리플라워, 콜라비 등은 십자화 과(Cruciferae) 채소에 속하며 전 세계인이 즐겨먹는 채소이 다. 십자화과 채소에는 glucosinolates(GS)라는 물질이 다량 함유되어 있는데, 이 물질은 황(sulfur)을 함유하는 물질로 현재까지 약 100 여종이 알려져 있으며 해충, 병원체 등에

*Corresponding author. E-mail : sblim@jejunu.ac.kr Phone : 82-64-754-3617, Fax : 82-64-755-3601

Received 30 October 2015; Revised 9 November 2015; Accepted 9 November 2015.

Copyright (c) The Korean Society of Food Preservation. All rights reserved.
대한 식물체의 방어기작에 중요한 역할을 한다(1-3).

그런데 GS 자체는 생리활성이 높지 않으나 채소류를 조리나 가공하는 과정 중에 조직이 파괴되면 채소 자체 내에 존재하는 가수분해 효소인 myrosinase(thioglycoside glucohydrolase)에 의해 생리활성이 높은 isothiocyanates (ITCs; $\mathrm{R}-\mathrm{N}=\mathrm{C}=\mathrm{S}$ )로 전환된다 $(4,5)$. 십자화과 채소의 생리 활성은 대부분 $\mathrm{GS}$ 의 가수분해 물질인 ITCs에 의한 것으로, 이들 물질들은 체내 detoxicating enzyme을 활성화시켜 암 을 예방하거나 면역기능을 나타내며 항산화 및 항산화 작용 을 증가시키는 것으로 알려져 있다(6-8). ITCs에는 다양한 성분들이 알려져 있는데, 그 중 sulforaphane은 브로콜리에, iberin은 브로콜리와 양배추에, erucin은 콜라비에, allyl ITC 는 양배추와 고추냉이에, raphasatin과 sulforaphene는 무에, 
phenylethyl ITC는 물냉이에, benzyl ITC는 와사비와 겨자에 주로 함유되어 있는 것으로 알려져 있다 $(2,9)$.

지금까지 ITCs에 의한 항균 효과는 주로 식품부패균에 대한 연구가 많이 수행되어 왔다 $(5,10)$. 특히 benzyl ITC와 allyl ITC는 그람양성균보다는 그람음성균에 대하여 높은 활성을 나타내었고, 세균보다는 곰팡이에 대하여 높은 활 성을 나타내는 것으로 알려져 있다(11). 또한 allyl ITC와 2-phenylethyl ITC는 Salmonella Montevideo, Escherichia coli, Listeria monocytogenes, Vibrio parahaemolyticus, Bacillus cereus, Bifidobacterium, Clostridium, Lactobacillus 에 대하여 항균성이 높은 것으로 알려져 있다(12).

한편 제주도에서 많이 양식하고 있는 넙치는 주로 병원 성 세균에 의하여 질병이 발생하여 경제적 피해를 주고 있는데, 주로 발생하는 세균성 질병은 Streptococcosis, edwardsiellosis, vibriosis에 의한 것으로 Streptococcosis의 원인 병원균으로는 $S$. parauberis와 $S$. iniae를, edwardsiellosis 의 원인종은 E. tarda와 E. ictaluri가 보고되고 있다. 또한 어류 vibriosis는 많은 종류의 Vibrio속 세균의 감염에 의하 여 해수어, 담수어 등 다양한 어류에서 발생하며, 특히 고밀 도 양식, 고염분과 유기물 오염이 높은 경우에 발생빈도가 높은 것으로 알려져 있는데, 공통적인 vibriosis의 원인균으 로는 $V$. anguillarum으로 보고되어 있으며 $V$. ordalli는 어류 의 출혈성 패혈증 원인균으로 알려져 있다(13).

지금까지 넙치 어병세균의 항균성에 대한 연구로는 천연 생약제 열수 및 알콜 추출물의 어병세균에 대한 항균활성 (14), 제주자생식물 열수 추출물의 어병세균인 E tarda, $S$. aureus 및 11종의 vibrio균에 대한 항균성(15), 오배자 추출 물의 어병세균에 대한 항균활성 $(16,17)$, 사료 내 마늘 추출 액 첨가가 넙치의 질병저항성에 미치는 영향(18) 등이 있다. 그러나 십자화과 채소 유래 isothiocyanates의 어병에 대한 항균성에 대한 연구는 보고된 바가 없다. 따라서 본 연구에 서는 십자화과 채소의 주요 성분인 10종의 isothiocyanates 와 무 가수분해물을 대상으로 6개의 넙치 어병세균에 대하 여 항균활성을 측정하여 ITCs의 화학적 구조와 항균성과의 관계를 비교하였다.

\section{재료 및 방법}

\section{실험재료}

본 실험에 사용한 10 종의 ITCs 중 benzyl ITC, indole-3-carbinol(I3C), allyl ITC(AITC), phenyl ITC(PITC), hexyl ITC(HITC)는 Sigma-Aldrich(MO, USA)의 제품을, phenylethyl ITC(PEITC), L-sulforaphene, R(-) iberin, erucin 은 Santa Cruz Biotechnology Inc.(Texas, USA)의 제품을, DL-sulforaphane은 Calbiochem(Merck Millipore, Darmstadt, Germany)의 제품을 사용하였다. 시료의 항균 효과와 비교
하기 위한 positive control로서 oxytetracycline(OTC)은 Sigma-Aldrich(MO, USA)의 제품을 사용하였고, 용매인 dimethyl sulfoxide(DMSO)는 Daejung Chemistry(Siheung, Korea)에서 구입하여 사용하였다.

본 실험에 사용된 무는 시중에 유통되고 있는 것을 마트 에서 구입하여, 세척, 절단, 동결 건조시킨 후, 분쇄기(Ika Work Inc., Wilmington, NC, USA)로 분쇄하여 $-20^{\circ} \mathrm{C}$ 냉동고 에 보관하면서 재료로 사용하였다.

시약 제조

본 실험에 사용한 각 ITCs의 stock solution은 $100 \%$ $\mathrm{DMSO}$ 에 2배씩 연속 희석하여 여러가지 농도의 용액을 제조하였다. 실험에 사용한 각 ITCs의 농도는 BITC, PEITC, I3C, AITC, HITC, PITC가 0.031 4.000 mg/mL, sulforaphane, sulforaphene, erucin, iberin이 $0.007 \sim 1.000 \mathrm{mg} / \mathrm{mL}$, OTC (positive control)이 $0.0001 \sim 0.400 \mathrm{mg} / \mathrm{mL}$, 무 가수분해물이 $3.9 \sim 0.500 \mathrm{mg} / \mathrm{mL}$ 이었다.

\section{무 가수분해물의 제조 및 $\mathrm{GC} / \mathrm{MS}$ 분석}

무 가수분해물은 $\mathrm{Kim}$ 등(19)의 방법에 준하여 제조하였 다. 동결 건조시킨 무 분말 $0.5 \mathrm{~g}$ 에 증류수 $8 \mathrm{~mL}$ 을 첨가하고, 내생효소에 의한 가수분해를 위해 $25^{\circ} \mathrm{C}$ 에서 10 분 동안 정치 반응시킨 후 dichlormethane $10 \mathrm{~mL}$ 을 첨가하여 $25^{\circ} \mathrm{C}$ 에서 15 분 동안 다시 교반 반응시켰다. 그 후 가수분해물은 dichlormethane으로 3회 추출하였고 anhydrous sodium sulfate(Sigma Co., MO, USA) $2 \mathrm{~g}$ 를 가하여 수분을 제거한 후 Advantec No. 5A 여과지로 여과하였다. 이것을 rotary vacuum evaporator(Rotavapor R-124, Büchi Labortechnik $\mathrm{AG}$, Flawil, Switzerland)로 상온에서 감압 농축하여 용매를 완전히 제거하였고 여기에 DMSO을 가하여 용해시킨 후 $-20^{\circ} \mathrm{C}$ 에 보관하면서 대상 균주에 대한 항균활성을 측정하 였고, $\mathrm{GC} / \mathrm{MS}$ 에 의한 주요 성분 분석은 dichlormethane에 용해하여 사용하였다.

무 가수분해물의 항균활성에 관여하는 주요 활성 성분을 명확히 하기 위하여 무 가수분해물 중의 ITCs는 Kim 등(19) 의 방법에 따라 Agilent 6890N GC/5973 MSD(Agilent Technologies, Santa Clara, CA, USA)로 분석하였다.

\section{사용 균주}

ITCs의 항균활성 실험에 사용한 균주는 양식넙치에서 분리한 어류 병원성 세균으로서 그람양성균 2종 (Streptococcus parauberis FP 3287, S. iniae FP 5228)과 그람 음성균 4종(Edwardsiella tarda FP 5060, Vibrio ichthyoenteri FP 4004, V. harveyi FP 8370, Photobacterium damselae FP 4101)은 국립수산과학원(National Institute of Fisheries Science; NIFS, Busan, Korea)으로부터 분양받아 사용하였 다. 각 균들은 $1 \%$ 소금이 첨가된 Brain Heart Infusion(BHI; 
Becton, Dickinson and Company, MD, USA)에서 배양하여 실험에 사용하였다. 각 균주의 배양조건은 Table 1 과 같으 며 3회 계대 배양하여 사용하였다.

Table 1. Fish pathogenic bacteria and incubation conditions used for the experiment

\begin{tabular}{clc}
\hline Gram & \multicolumn{1}{c}{ Strain } & $\begin{array}{c}\text { Incubation } \\
\text { condition }\end{array}$ \\
\hline \multirow{2}{*}{$(+)$} & Streptococcus parauberis FP 3287 & $37^{\circ} \mathrm{C}, 24 \mathrm{hr}$ \\
& Streptococcus iniae FP 5228 & $37^{\circ} \mathrm{C}, 48 \mathrm{hr}$ \\
\hline \multirow{4}{*}{$(-)$} & Edwardsiella tarda FP 5060 & $37^{\circ} \mathrm{C}, 24 \mathrm{hr}$ \\
& Vibrio ichthyoenteri FP 4004 & $37^{\circ} \mathrm{C}, 24 \mathrm{hr}$ \\
& Vibrio harveyi FP 8370 & $37^{\circ} \mathrm{C}, 24 \mathrm{hr}$ \\
& Photobacterium damselae FP 4101 & $37^{\circ} \mathrm{C}, 24 \mathrm{hr}$ \\
\hline
\end{tabular}

\section{최소저해농도 $(\mathrm{MIC})$ 측정}

ITCs의 최소저해농도(MIC)는 Clinical and Laboratory Standards Institute(20)의 표준방법에 따라 broth microdilution method를 변형하여 측정하였다. 즉, stock solution을 $1 \%$ 소금이 첨가된 $\mathrm{BHI}$ 배지로 100 배 희석하여 96-well round-bottom plate에 $100 \mu \mathrm{L}$ 씩 분주하였다. 각각의 접종균 은 $1 \%$ 소금이 첨가된 $\mathrm{BHI}$ broth에 $0.5 \mathrm{McFarland}$ 농도 $\left(1 \times 10^{8} \mathrm{CFU} / \mathrm{mL}\right)$ 가 되도록 미리 배양한 후 $5 \times 10^{6} \mathrm{CFU} / \mathrm{mL}$ 이 되도록 희석하여 각 well에 $5 \mu \mathrm{L}$ 씩 접종하였고, $37^{\circ} \mathrm{C}$ 에서
24 48시간 동안 배양한 후에 육안으로 세균이 자라지 않은 최저 농도를 MIC 값으로 결정하였다. 음성대조군으로는 멸균 증류수와 $1 \% \mathrm{DMSO}$ 를 사용하였고, 양성 대조군으로 는 OTC를 사용하였다.

\section{최소살균농도 $(\mathrm{MBC})$ 측정}

$\mathrm{ITCs}$ 의 최소살균농도(MBC)는 $\mathrm{MIC}$ 측정 후 증식이 관찰 되지 않은 배양액을 한 백금이 취하여 $1 \%$ 소금이 첨가된 $\mathrm{BHI}$ 평판배지에 도말한 후, $37^{\circ} \mathrm{C}$ 에서 24 48시간 동안 배양 하여 colony가 관찰되지 않은 최소 농도를 최소살균농도 (MIC)로 결정하였다.

\section{통계처리}

모든 실험은 최소 4 회 반복실시 하였으며, 실험 결과는 평균값과 표준편차로 나타내었다. 통계처리는 SPSS 통계 분석 프로그램을 이용하여 one-way ANOVA 분석을 실시 한 후 각 실험군간 평균치의 통계적 유의성 $(\mathrm{p}<0.05)$ 을 Duncan's multiple range test로 실시하였다.

\section{결과 및 고찰}

$\mathrm{ITCs}$ 의 최소저해농도 (MIC)와 최소살균농도( $\mathrm{MBC}$ )

어류의 세균성 질병을 일으키는 대표적인 어병 세균으로 써 그람양성균 2종(S. parauberis, S. iniae)과 그람음성균

Table 2. Minimum inhibitory concentration $(\mathrm{mg} / \mathrm{mL})$ of pure isothiocyanates and radish root hydrolysate against fish pathogenic bacteria

\begin{tabular}{|c|c|c|c|c|c|c|}
\hline \multirow{2}{*}{ Isothiocyanates } & \multicolumn{6}{|c|}{ Fish pathogenic bacteria } \\
\hline & S. parauberis & S. iniae & E. $\operatorname{tarda}$ & V. ichthyoenteri & V. harveyi & P. damselae \\
\hline \multicolumn{7}{|l|}{ Aliphatic ITC ${ }^{1)}$} \\
\hline Sulforaphane & $0.500 \pm 0.000^{\mathrm{b}(3)}$ & $0.094 \pm 0.036^{\mathrm{ef}}$ & $0.063 \pm 0.000^{\mathrm{ef}}$ & $1.000 \pm 0.000^{\mathrm{b}}$ & $0.125 \pm 0.000^{\mathrm{cd}}$ & $0.188 \pm 0.072^{\mathrm{bc}}$ \\
\hline Sulforaphene & $0.125 \pm 0.000^{\mathrm{cd}}$ & $0.250 \pm 0.000^{\mathrm{d}}$ & $0.078 \pm 0.031^{\mathrm{ef}}$ & $1.000 \pm 0.000^{\mathrm{b}}$ & $0.125 \pm 0.000^{\text {cd }}$ & $0.250 \pm 0.000^{\mathrm{bc}}$ \\
\hline Iberin & $0.156 \pm 0.063^{\mathrm{cd}}$ & $0.250 \pm 0.000^{\mathrm{d}}$ & $0.188 \pm 0.210^{\mathrm{de}}$ & $1.000 \pm 0.000^{\mathrm{b}}$ & $0.250 \pm 0.000^{c}$ & $0.438 \pm 0.125^{\mathrm{b}}$ \\
\hline Erucin & $0.750 \pm 0.289^{b}$ & $0.094 \pm 0.036^{\mathrm{ef}}$ & $0.063 \pm 0.000^{\mathrm{ef}}$ & $1.000 \pm 0.000^{\mathrm{b}}$ & $0.063 \pm 0.000^{\mathrm{cd}}$ & $0.125 \pm 0.000^{\mathrm{c}}$ \\
\hline Allyl ITC & $0.750 \pm 0.289^{b}$ & $>4.000$ & $0.500 \pm 0.000^{c}$ & $>4.000$ & $0.500 \pm 0.354^{\mathrm{b}}$ & $0.667 \pm 0.289^{\mathrm{a}}$ \\
\hline Hexyl ITC & $>4.000$ & $4.000 \pm 0.000^{\mathrm{a}}$ & $>4.000$ & $>4.000$ & $>4.000$ & $>4.000$ \\
\hline \multicolumn{7}{|l|}{ Aromatic ITC } \\
\hline Phenylethyl ITC & $0.188 \pm 0.072^{\mathrm{cd}}$ & $0.625 \pm 0.250^{\mathrm{c}}$ & $0.250 \pm 0.000^{\mathrm{d}}$ & $0.625 \pm 0.250^{\mathrm{c}}$ & $0.125 \pm 0.000^{\mathrm{cd}}$ & $0.219 \pm 0.063^{\mathrm{bc}}$ \\
\hline Benzyl ITC & $0.500 \pm 0.000^{\mathrm{bc}}$ & $0.219 \pm 0.063^{\mathrm{de}}$ & $0.313 \pm 0.125^{\mathrm{d}}$ & $0.750 \pm 0.288^{b c}$ & $0.125 \pm 0.000^{\mathrm{cd}}$ & $0.375 \pm 0.144^{\mathrm{bc}}$ \\
\hline Phenyl ITC & $1.500 \pm 0.577^{\mathrm{a}}$ & $2.000 \pm 0.0000^{\mathrm{b}}$ & $4.000 \pm 0.000^{\mathrm{a}}$ & $4.000 \pm 0.000^{\mathrm{a}}$ & $4.000 \pm 0.000^{\mathrm{a}}$ & $>4.000$ \\
\hline \multicolumn{7}{|l|}{ Indolyl ITC } \\
\hline Indole-3-carbinol & $0.375 \pm 0.144^{\text {bcd }}$ & $0.125 \pm 0.000^{\mathrm{def}}$ & $1.000 \pm 0.000^{b}$ & $0.313 \pm 0.125^{d}$ & $0.500 \pm 0.000^{b}$ & $0.375 \pm 0.144^{\mathrm{bc}}$ \\
\hline Hydrolysate of radish root & $0.438 \pm 0.125^{\mathrm{bc}}$ & $0.250 \pm 0.000^{\mathrm{d}}$ & $0.500 \pm 0.000^{c}$ & $>0.500$ & $0.500 \pm 0.000^{\mathrm{b}}$ & $>0.500$ \\
\hline Oxytetracycline ${ }^{2)}$ & $0.0003 \pm 0.0000^{\mathrm{d}}$ & $0.0027 \pm 0.0008^{\mathrm{f}}$ & $0.0007 \pm 0.0000^{f}$ & $0.0009 \pm 0.0004^{\mathrm{e}}$ & $0.0004 \pm 0.0000^{\mathrm{d}}$ & $0.350 \pm 0.100^{\mathrm{bc}}$ \\
\hline
\end{tabular}

${ }^{1)}$ ITC, isothiocyanate.

${ }^{2)}$ Oxytetracycline, positive control.

${ }^{3)}$ Values are expressed as mean $\pm \mathrm{SD}(\mathrm{n}=4)$. Means with different superscripts in the same column are significantly different by Duncan's multiple rage test $(\mathrm{p}<0.05)$. 
6종(E. tarda, V. ichthyoenteri, V. harveyi, P. damselae)에 대하여 십자화과 채소 유래 10 종의 ITCs와 무 가수분해물 의 항균활성을 측정하여 최소저해농도(MIC)와 최소살균 농도(MBC)로 나타내었다(Table 2, 3). 항균활성은 전체적 으로 sulforaphane, sulforaphene, PEITC, erucin, BITC, iberin, $\mathrm{I} 3 \mathrm{C}$ 가 높았으며, AITC, PITC, HITC는 낮았다. 어병 세균별로 ITCs에 대한 민감성은 V. harveyi가 가장 높았으 며, 그 다음으로 E. tarda, P. damselae, S. parauberis, S. iniae, $V$. ichthyoenteri 순으로, $V$. ichthyoenteri을 제외하고는 그람음성균이 그람양성균에 비하여 민감성이 높았다.

각 ITC 별로 항균활성을 보면, sulforaphane은 브로콜리 의 주요 GS인 glucoraphanine의 가수분해물로써, 최소저해 농도(MIC)는 $E . t a r d a$ 에 대해서 $0.063 \mathrm{mg} / \mathrm{mL}$ 로 항균활성이 가장 높았고, $S$. iniae $(0.094 \mathrm{mg} / \mathrm{mL}), \quad V$. harveyi $(0.125$ $\mathrm{mg} / \mathrm{mL}), P$. damselae $(0.188 \mathrm{mg} / \mathrm{mL}), S$. parauberis $(0.500$ $\mathrm{mg} / \mathrm{mL}$ )에 대해서도 높은 항균활성을 나타내었다. Sulforaphane의 최소살균농도(MBC)는 약 $2 \times \mathrm{MIC}$ 이하인 것으로 보아 sulforaphane은 살균효과가 있는 것으로 추정 되었다.

Sulforaphene은 무에 두 번째로 많이 함유되어 있는 glucoraphenine의 가수분해물로써, 어병 세균에 대한 최소 저해농도(MIC)는 $E . \operatorname{tarda}$ 는 $0.078 \mathrm{mg} / \mathrm{mL}$ 로 가장 높았고, V. harveyi와 S. parauberis는 $0.125 \mathrm{mg} / \mathrm{mL}, P$. damselae와 $S$. iniae는 $0.250 \mathrm{mg} / \mathrm{mL}$ 로 높은 항균활성을 나타내었다.
Sulforaphene의 $\mathrm{MBC}$ 은 약 $3 \times \mathrm{MIC}$ 이상인 것으로 보아 sulforaphene은 정균효과가 있는 것으로 추정되었다. 특히 V. ichthyoenteri의 경우 sulforaphane과 sulforaphene의 MIC 이 $1.000 \mathrm{mg} / \mathrm{mL}$ 로 항균활성이 낮은 것으로 보아 다른 균주 에 비하여 내성이 강한 것으로 추정되었다.

PEITC는 물냉이의 주요 GS인 gluconasturtin의 가수분해 생성물로써, 어병 세균 중에서 $V$. harveyi $(0.125 \mathrm{mg} / \mathrm{mL})$ 에 대하여 가장 높은 항균활성을 나타내었다. 또한 $S$. parauberis $(0.188 \mathrm{mg} / \mathrm{mL}), P$. damselae $(0.219 \mathrm{mg} / \mathrm{mL}), E$. $\operatorname{tarda}(0.250 \mathrm{mg} / \mathrm{mL})$ 에 대해서도 높은 항균성을 보였으나, S. iniae와 $V$. ichthyoenteri에 대해서는 $0.625 \mathrm{mg} / \mathrm{mL}$ 으로 다소 낮은 항균성을 나타내었다. PEITC의 $\mathrm{MBC}$ 는 $\mathrm{MIC}$ 과 일치하거나 $2 \times \mathrm{MIC}$ 이하인 것으로 보아 살균효과를 나타내 는 것으로 추정되었다.

Erucin은 순무나 콜라비에 많이 함유되어있는 glucoerucin 의 가수분해 생성물로서, MIC은 E. tarda와 V. harveyi에 대해서 $0.063 \mathrm{mg} / \mathrm{mL}$ 로 강한 항균활성을 나타내었다. 그리 고 $S$. iniae $(0.094 \mathrm{mg} / \mathrm{mL})$ 와 $P$. damselae $(0.125 \mathrm{mg} / \mathrm{mL})$ 에 대하서도 높은 항균활성을 나타내었으나, $S$. parauberis $(0.750 \mathrm{mg} / \mathrm{mL})$ 와 $V$. ichthyoenteri $(1.000 \mathrm{mg} / \mathrm{mL})$ 에 대해서는 낮은 항균활성을 나타내었다. Erucin의 $\mathrm{MBC}$ 은 $\mathrm{MIC}$ 과 일 치하거나 $2 \times \mathrm{MIC}$ 이하인 것으로 보아 살균효과를 나타내는 것으로 추정되었다.

BITC는 와사비나 겨자에 많이 함유되어 있는 glucotropaeolin의 가수분해물로써, MIC은 V. harveyi에 대해서

Table 3. Minimum bactericidal concentration $(\mathrm{mg} / \mathrm{mL})$ of pure isothiocyanates and radish root hydrolysate against fish pathogenic bacteria

\begin{tabular}{|c|c|c|c|c|c|c|}
\hline \multirow{2}{*}{ Isothiocyanates } & \multicolumn{6}{|c|}{ Fish pathogenic bacteria } \\
\hline & S. parauberis & $S$. iniae & E. tarda & V. ichthyoenteri & V. harveyi & P. damselae \\
\hline \multicolumn{7}{|l|}{ Aliphatic ITC ${ }^{1)}$} \\
\hline Sulforaphane & $0.875 \pm 0.250^{(3)}$ & $0.281 \pm 0.157^{\mathrm{bc}}$ & $0.125 \pm 0.000^{c}$ & $>1.000$ & $0.125 \pm 0.000^{\mathrm{b}}$ & $0.250 \pm 0.000^{\mathrm{cd}}$ \\
\hline Sulforaphene & $1.000 \pm 0.000^{c}$ & $1.000 \pm 0.000^{\mathrm{a}}$ & $0.219 \pm 0.063^{\mathrm{c}}$ & $>1.000$ & $0.219 \pm 0.063^{\mathrm{b}}$ & $0.250 \pm 0.000^{\mathrm{cd}}$ \\
\hline Iberin & $1.000 \pm 0.000^{c}$ & $1.000 \pm 0.000^{\mathrm{a}}$ & $0.500 \pm 0.000^{b}$ & $>1.000$ & $0.250 \pm 0.000^{b}$ & $0.500 \pm 0.000^{\mathrm{b}}$ \\
\hline Erucin & $0.750 \pm 0.289^{\mathrm{cd}}$ & $0.500 \pm 0.354^{\mathrm{b}}$ & $0.125 \pm 0.000^{c}$ & $>1.000$ & $0.063 \pm 0.000^{b}$ & $0.125 \pm 0.000^{\mathrm{d}}$ \\
\hline Allyl ITC & $4.000 \pm 0.000^{\mathrm{a}}$ & $>4.000$ & $0.500 \pm 0.000^{\mathrm{b}}$ & $>4.000$ & $1.313 \pm 1.796^{\mathrm{a}}$ & $0.833 \pm 0.289^{\mathrm{a}}$ \\
\hline Hexyl ITC & $>4.000$ & $>4.000$ & $>4.000$ & $>4.000$ & $>4.000$ & $>4.000$ \\
\hline \multicolumn{7}{|l|}{ Aromatic ITC } \\
\hline Phenylethyl ITC & $0.313 \pm 0.125^{\mathrm{cd}}$ & $1.125 \pm 0.629^{\mathrm{a}}$ & $0.438 \pm 0.125^{\mathrm{b}}$ & $1.000 \pm 0.000^{\mathrm{a}}$ & $0.125 \pm 0.000^{b}$ & $0.313 \pm 0.125^{\mathrm{bcd}}$ \\
\hline Benzyl ITC & $0.625 \pm 0.250^{\text {cd }}$ & $0.250 \pm 0.0000^{\mathrm{bc}}$ & $0.500 \pm .0 .354^{\mathrm{b}}$ & $1.000 \pm 0.000^{\mathrm{a}}$ & $0.125 \pm 0.000^{b}$ & $0.438 \pm 0.125^{\mathrm{bc}}$ \\
\hline Phenyl ITC & $2.000 \pm 1.414^{b}$ & $>4.000$ & $>4.000$ & $>4.000$ & $>4.000$ & $>4.000$ \\
\hline \multicolumn{7}{|l|}{ Indolyl ITC } \\
\hline Indole-3-carbinol & $0.375 \pm 0.144^{\text {cd }}$ & $0.250 \pm 0.000^{\mathrm{bc}}$ & $1.000 \pm 0.000^{\mathrm{a}}$ & $0.813 \pm 0.800^{\mathrm{a}}$ & $0.500 \pm 0.000^{\mathrm{ab}}$ & $0.438 \pm 0.125^{\mathrm{bc}}$ \\
\hline Hydrolysate of radish root & $0.500 \pm 0.000^{\mathrm{cd}}$ & $0.250 \pm 0.000^{\mathrm{bc}}$ & $>0.500$ & $>0.500$ & $0.500 \pm 0.000^{\mathrm{ab}}$ & $>0.500$ \\
\hline Oxytetracycline $e^{2)}$ & $0.0008 \pm 0.0000^{\mathrm{d}}$ & $0.0047 \pm 0.0018^{\mathrm{c}}$ & $0.0031 \pm 0.000^{c}$ & $0.0027 \pm 0.0024^{\mathrm{b}}$ & $0.0008 \pm 0.0000^{b}$ & $0.350 \pm 0.100^{b c d}$ \\
\hline
\end{tabular}


$0.125 \mathrm{mg} / \mathrm{mL}$ 로 강한 항균활성을 나타내었다. 그리고 $S$. iniae $(0.219 \mathrm{mg} / \mathrm{mL})$, E. tarda $(0.313 \mathrm{mg} / \mathrm{mL})$, P. damselae $(0.375 \mathrm{mg} / \mathrm{mL}), S$ parauberis $(0.500 \mathrm{mg} / \mathrm{mL})$ 에 대해서도 높 은 항균성을 나타내었다. $\mathrm{BITC}$ 의 $\mathrm{MBC}$ 는 $\mathrm{MIC}$ 과 일치하거 나 $2 \times \mathrm{MIC}$ 이하인 것으로 보아 살균효과를 나타내는 것으 로 추정되었다.

Iberin은 브로콜리와 양배추의 주요 $\mathrm{GS}$ 인 glucoiberin의 가수분해물로서, $\mathrm{MIC}$ 은 S parauberis와 E. tarda 대해 각각 0.156 과 $0.188 \mathrm{mg} / \mathrm{mL}$ 로 높은 항균활성을 나타내었다. 또한 V. harveyi와 S. iniae와 P. damselae에 대해서는 각각 0.250 과 $0.438 \mathrm{mg} / \mathrm{mL}$ 로 높은 항균활성을 나타내었지만, $V$. ichthyoenteri에 대해서는 $1.000 \mathrm{mg} / \mathrm{mL}$ 라는 비교적 낮은 항 균활성을 나타내었다. Iberin의 $\mathrm{MBC}$ 은 $\mathrm{MIC}$ 과 일치하거나 약 $3 \times \mathrm{MIC}$ 이하인 것으로 보아 살균효과 또는 정균효과가 있는 것으로 추정되었다.

$\mathrm{I} 3 \mathrm{C}$ 는 모든 십자화과 채소에 함유되어 있는 glucobrassicin 의 가수분해물로서, $\mathrm{MIC}$ 은 $S$. iniae에 대해서 $0.125 \mathrm{mg} / \mathrm{mL}$ 로 가장 높은 항균활성을 나타내었고, $V$. ichthyoenteri(0.313 $\mathrm{mg} / \mathrm{mL}), S$. parauberis와 $P$. damselae $(0.375 \mathrm{mg} / \mathrm{mL}), V$. harveyi $(0.500 \mathrm{mg} / \mathrm{mL})$ 에서도 높은 항균활성을 나타내었지 만, E. tarda에 대해서는 $1.000 \mathrm{mg} / \mathrm{mL}$ 라는 비교적 낮은 항균 활성을 나타내었다. $\mathrm{I} 3 \mathrm{C}$ 의 $\mathrm{MBC}$ 는 $\mathrm{MIC}$ 과 일치하거나 약 $2 \times \mathrm{MIC}$ 이하인 것으로 보아 살균효과가 있는 것으로 추정 되었다. $\mathrm{I} 3 \mathrm{C}$ 는 특히 $V$. ichthyoenteri $(0.313 \mathrm{mg} / \mathrm{mL})$ 에 대하여 높은 항균활성을 나타내었다.

$\mathrm{AITC}$ 는 양배추와 겨자에 많이 함유되어 있는 sinigrin의 가수분해물로서, $\mathrm{MIC}$ 은 E. tarda와 V. harveyi에 대해서 $0.500 \mathrm{mg} / \mathrm{mL}, P$. damselae에 대해서는 $0.667 \mathrm{mg} / \mathrm{mL}, S$. parauberis에 대해서는 $0.750 \mathrm{mg} / \mathrm{mL}$ 의 항균활성을 나타내 었으나, S. iniae와 V. ichthyoenteri에 대해서는 >4.000 $\mathrm{mg} / \mathrm{mL}$ 로 낮은 항균활성을 나타내었다. $\mathrm{AITC}$ 의 $\mathrm{MBC}$ 는 $\mathrm{MIC}$ 과 일치하거나, 약 $3 \times \mathrm{MIC}$ 이하인 것으로 보아 살균효 과 또는 정균효과가 있는 것으로 추정되었다.

$\operatorname{Kim}$ 등(21)은 양식넙치에서 분리한 E. tarda 49개 균주에 대하여 시판되고 있는 항생제에 대한 항균활성 $\left(\mathrm{MIC}_{90}\right)$ 을 측정한 결과 ampicillin, amoxicillin, doxycycline, oxolinic acid, flumequine, ciprofloxacin, norfloxacin이 각각 0.032, $0.032,0.064,0.016,0.016,0.0005,0.001 \mathrm{mg} / \mathrm{mL}$ 로, 본 연구 에서의 sulforaphane $(0.063 \mathrm{mg} / \mathrm{mL})$, sulforaphene(0.078), iberin(0.188), erucin(0.063), phenylethyl ITC(0.250), benzyl $\mathrm{ITC}(0.313)$ 와 비교하였을 때 시판 항생제가 높은 항균활성 을 나타내었다.

ITCs의 항균활성과 비교하기 위하여 positive control로 양식 어류의 세균성 질병 치료제인 OTC를 사용하여 항균 활성을 측정하였다. $\mathrm{MIC}$ 은 $S$. parauberis, $S$. iniae, E. tarda, $V$. ichthyoenteri, $V$. harveyi에 대해서 $0.0003 \sim 0.0027 \mathrm{mg} / \mathrm{mL}$ 로 매우 높은 항균활성을 나타내었으나, P. damselae에 대
해서는 $0.350 \mathrm{mg} / \mathrm{mL}$ 로 가장 낮은 항균활성을 나타내었다. 따라서 OTC는 실험에 사용한 10 종의 ITC 보다 매우 높은 항균활성을 나타내었다. Bulfon 등(22)도 P. damselae를 포 함한 5종의 어병세균에 대하여 OTC의 항균활성을 측정한 결과 다른 세균들에 비하여 $P$. damselae에 대해서 낮은 항균 활성을 나타낸다고 보고한 것으로 보아 P. damselae가 타 세균들에 비하여 OTC에 대한 내성이 강한 것으로 추정되 었다. 반면 몇가지 ITCs(sulforaphane, sulforaphene, PEITC, enucin)는 OTC 보다 P. damselae에 대한 항균성이 높은 것으 로 보아 P. damselae의 살균에 ITCs의 이용 가능성을 고려 할 수 있을 것으로 추정되었다.

\section{무 가수분해물의 최소저해농도 $(\mathrm{MIC})$ 및 최소살균농도 (MBC)}

넙치 어병 세균 6종에 대한 무 가수분해물의 $\mathrm{MIC}$ 과 $\mathrm{MBC}$ 를 측정하였다(Table 2와 3). 무 가수분해물의 항균활성에 관여하는 주요 활성 성분을 확인하기 위하여 $\mathrm{GC} / \mathrm{MS}$ 로 분 석한 결과 raphasatin과 sulforaphene이라는 두 개의 ITC 성 분만이 검출되었고(Fig. 1) 그 농도(ppm) 비율은 1:0.16이었 다. Raphasatin은 화학 구조상 erucin과 비슷하지만 불안정 하여 타 물질로 쉽게 전환되기 때문에 시판되고 있지 않다 (23). 무 가수분해물의 $\mathrm{MIC}$ 은 S. iniae에 대해서 0.250 $\mathrm{mg} / \mathrm{mL}$ (raphasatin의 농도)로 가장 높은 항균활성을 나타내 었고, $S$. parauberis는 $0.438 \mathrm{mg} / \mathrm{mL}, E$. tarda와 $V$. harveyi는 $0.500 \mathrm{mg} / \mathrm{mL}$ 로 높은 항균활성을 나타내었다. P. damselae 와 $V$. ichthyoenteri에 대해서는 $>0.500 \mathrm{mg} / \mathrm{mL}$ 로 비교적 낮 은 항균활성을 나타내었다. $\mathrm{Kim}$ 등(17)은 오배자의 $80 \%$ methanol 추출물의 S. iniae와 V. ichthyoenteri에 대한 $\mathrm{MIC}$ 은 각각 0.128 과 $0.032 \mathrm{mg} / \mathrm{mL}$ 로 무 가수분해물 $(0.250$ 과 $>0.500$ $\mathrm{mg} / \mathrm{mL}$ ) 보다 높은 항균활성을 보고하였다. Han 등(24)은 봉독(honeybee venom)의 항균성 $(\mathrm{MIC})$ 을 측정한 결과 $E$. tarda, S. iniae, V. ichthyoenteri에 대해서 각각 0.0176, 0.0034, $0.0017 \mathrm{mg} / \mathrm{mL}$ 로 무 가수분해물보다 항균활성이 높았다.

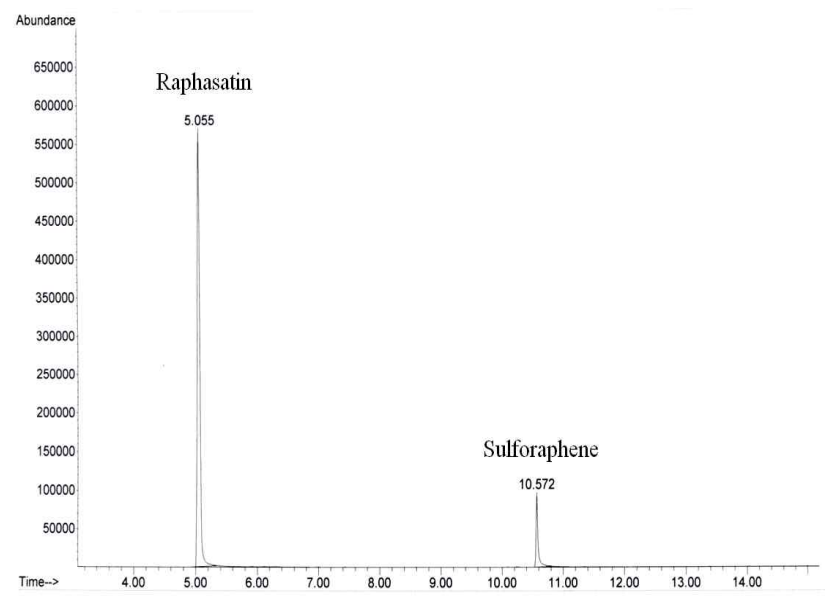

Fig. 1. GC/MS chromatogram of radish root hydrolysate. 
Kang 등(25)은 제주 자생식물 추출물의 항균활성(MIC)을 측정한 결과 $S$ iniae인 경우에는 짚신나물이 $1 \mathrm{mg} / \mathrm{mL}$, 독활 과 섬바디나물은 $3 \mathrm{mg} / \mathrm{mL}$, 나도송이풀은 $4 \mathrm{mg} / \mathrm{mL}$ 로 낮은 항균활성을 나타내었고, E tarda에 대해서는 물참나무, 서 나무, 세잎쥐손이가 각각 $4,5,>5 \mathrm{mg} / \mathrm{mL}$ 로 본 연구에서의 무 가수분해물보다 낮은 활성을 나타내었다. 이 외에 넙치 어병세균에 대한 항균성 연구로 천연 생약제 열수 및 알콜 추출물(14), 제주자생식물 열수 추출물(15), 오배자 추출물 (16), 마늘 추출액(18) 등이 있으나, paper disc법으로 항균활 성을 측정하여 농도면에서 본 연구와 비교하기가 어려웠 다. 한편 무 가수분해물의 $\mathrm{MBC}$ 은 $\mathrm{MIC}$ 과 일치하거나 $2 \times \mathrm{MIC}$ 로 살균효과가 있는 것으로 추정되었다.

\section{ITCs의 구조와 항균활성과의 관계}

ITCs는 화학구조에 따라 aliphatic ITCs, aromatic ITCs, indolyl ITCs로 나누어지는데, aliphatic ITCs에는 sulforaphane, sulforaphene, iberin, erucin, AITC, HITC이 속하며, aromatic ITCs에는 PEITC, BITC, PITC이 있으며, indolyl ITCs에는 $\mathrm{I} 3 \mathrm{C}$ 가 있다.

ITCs의 화학구조에 따른 항균활성을 보면, 먼저 hydrocarbon chain으로 이루어진 aliphatic ITCs 중에서는 sulforaphene, sulforaphane, erucin, iberin의 항균활성이 높았으며, benzene ring을 함유하고 있는 aromatic ITCs 중에서는 PEITC과 BITC의 항균활성이 높았지만, indole group을 함 유하고 있는 indolyl ITC인 I3C는 항균활성이 그다지 높지 않았다. Wilson 등(12)은 식품부패 미생물에 대하여, Dias 등(5)은 methicillin 내성 균주인 $S$ aureus 여러 종에 대하여 ITCs의 항균활성을 측정한 결과 aromatic ITCs가 aliphatic ITCs에 비하여 항균활성이 높다고 보고하여 본 연구결과와 다른 경향을 나타내었다.

한편 구조가 동일하지만 화학구조에 있어서 이중결합이 없는 sulforaphane $\left(\mathrm{CH}_{3}-\mathrm{SO}-\mathrm{CH}_{2}-\mathrm{CH}_{2}-\mathrm{CH}_{2}-\mathrm{CH}_{2}-\right.$ 은 이중결 합을 가지고 있는 sulforaphene $\left(\mathrm{CH}_{3}-\mathrm{SO}-\mathrm{CH}=\mathrm{CH}-\mathrm{CH}_{2}-\mathrm{CH}_{2}-\right)$ 에 비하여 항균활성이 대부분의 균주에 대해서 높았다. 즉, sulforaphane의 $\mathrm{MIC}$ 은 E. tarda, S. iniae, V. harveyi, $P$. damselae에 대하여 각각 $0.063,0.094,0.125,0.188 \mathrm{mg} / \mathrm{mL}$ 로 sulforaphene의 $0.078,0.250,0.125,0.250 \mathrm{mg} / \mathrm{mL}$ 에 비하여 낮았다. 또한 화학구조에 있어서 thiol(-S-) 또는 sulfinyl (-SO-) group의 존재 여부도 항균활성에 영향을 미쳤다. 즉, thiol group을 가지고 있는 erucin $\left(\mathrm{CH}_{3}-\mathrm{S}_{-}-\mathrm{CH}_{2}-\mathrm{CH}_{2}-\mathrm{CH}_{2}-\mathrm{CH}_{2}-\right)$ 의 $\mathrm{MIC}$ 은 V. harveyi, P. damselae에 대하여 각각 0.063 , $0.125 \mathrm{mg} / \mathrm{mL}$ 로 sulfinyl group을 가지고 있는 sulforaphane $\left(\mathrm{CH}_{3}-\mathrm{SO}-\mathrm{CH}_{2}-\mathrm{CH}_{2}-\mathrm{CH}_{2}-\mathrm{CH}_{2-}\right)$ 의 $0.125,0.188 \mathrm{mg} / \mathrm{mL}$ 에 비 하여 낮아 항균활성이 높았다.

탄소사슬의 길이에 따른 항균활성을 보면, 탄소사슬의 길이가 긴 $\mathrm{PEITC}\left(\mathrm{C}_{6} \mathrm{H}_{5}-\mathrm{CH}_{2}-\mathrm{CH}_{2}\right)$ 의 $\mathrm{MIC}$ 은 E. tarda, $P$. damselae, S. parauberis, S. iniae에 대하여 각각 0.250, 0.219,
$0.188,0.625 \mathrm{mg} / \mathrm{mL}$ 로 탄소사슬의 길이가 짧은 $\mathrm{BITC}$ $\left(\mathrm{C}_{6} \mathrm{H}_{5}-\mathrm{CH}_{2^{-}}\right)$의 $0.313,0.375,0.500,0.750 \mathrm{mg} / \mathrm{mL}$ 보다 낮아 높은 항균활성을 나타내었다. 또한 탄소사슬의 길이가 긴 sulforaphane $\left(\mathrm{CH}_{3}-\mathrm{SO}-\mathrm{CH}_{2}-\mathrm{CH}_{2}-\mathrm{CH}_{2}-\mathrm{CH}_{2}-\right)$ 의 $\mathrm{MIC}$ 은 $V$. harvey, E. tarda, P. damselae, S. iniae에 대하여 각각 0.125, $0.063,0.188,0.094 \mathrm{mg} / \mathrm{mL}$ 로서 탄소사슬의 길이가 짧은 iberin $\left(\mathrm{CH}_{3}-\mathrm{SO}-\mathrm{CH}_{2}-\mathrm{CH}_{2}-\mathrm{CH}_{2}-\right)$ 의 $0.250,0.188,0.438,0.250$ $\mathrm{mg} / \mathrm{mL}$ 보다 낮아 높은 항균활성을 나타내었다. Wilson 등 (12)은 탄소사슬의 길이가 짧은 ITCs가 탄소사슬의 길이가 긴 ITCs에 비하여 식품부패 미생물에 대하여 높은 항균활 성을 나타내었다고 보고하였는데, 균의 종류에 따라 항균 성이 다를 수 있을 것으로 추정되었다.

\section{요 약}

십자화과 채소의 주요 성분인 10종의 isothiocyanates (ITCs)와 무 가수분해물을 대상으로 6개의 넙치 어병세균 에 대하여 항균활성을 측정하여 ITCs의 화학적 구조와 항 균성과의 관계를 비교하였다. 항균활성은 sulforaphane, sulforaphene, PEITC, erucin, BITC, iberin, I3C가 높았으며, $\mathrm{AITC}, \mathrm{PITC}, \mathrm{HITC}$ 는 낮았다. 어병 세균별로 ITCs에 대한 민감성은 $V$ harvey가 가장 높았으며, 그 다음으로 E tarda, P. damselae, S. parauberis, S. iniae, V. ichthyoenteri 순으로, 그람음성균이 그람양성균에 비하여 민감성이 높았다. 무 가수분해물의 최소저해농도(MIC)는 $S$ iniae에 대해서 $0.250 \mathrm{mg} / \mathrm{mL}$ (raphasatin의 농도)로 가장 높은 항균활성을 나타내었고, $S$. parauberis는 $0.438 \mathrm{mg} / \mathrm{mL}, E$. tarda와 $V$. harveyi는 $0.500 \mathrm{mg} / \mathrm{mL}$ 로 높은 항균활성을 나타내었다. ITCs의 화학구조에 따른 어병 세균에 대한 항균활성은 aliphatic ITCs 중에서는 sulforaphene, sulforaphane, erucin, iberin의 항균활성이 높았으며, benzene ring을 함유하고 있 는 aromatic ITCs 중에서는 PEITC과 BITC이 가장 항균활성 이 높았다. 이중결합이 없는 sulforaphane은 이중결합을 가 지고 있는 sulforaphene에 비하여 항균활성이 대부분의 균 주에 대해서 높았다. Thiol group을 가지고 있는 erucin은 sulfinyl group을 가지고 있는 sulforaphane에 비하여 일부 균주에 대하여 높은 항균활성을 나타내었다. 탄소사슬의 길이가 긴 PEITC는 탄소사슬의 길이가 짧은 BITC에 비하 여 4가지 균주에 대하여 항균활성이 높았다. 이상의 결과로 부터 십자화과 유래 ITCs는 넙치 어병 항균제로 활용할 수 있을 것으로 추정되었다.

\section{References}

1. Wennberg M, Ekvall J, Olsson K, Nyman M (2006) 
Changes in carbohydrate and glucosinolate composition in white cabbage (Brassica oleracea var. capitata) during blanching and treatment with acetic acid. Food Chem, 95, 226-236

2. Clarke DB (2010) Glucosinolates, structures and analysis in food. Anal Methods, 2, 310-325

3. Agerbirk N, Olsen CE (2012) Glucosinolate structures in evolution. Phytochem, 77, 16-45

4. Bones AM, Rossiter JT (1996) The myrosinase-glucosinolate system, its organisation and biochemistry. Physiol Plant, 97, 194-208

5. Dias C, Aires A, Saavedra MJ (2014) Antimicrobial activity of isothiocyanates from cruciferous plants against methicillin-resistant Staphylococcus aureus (MRSA). Int J Mol Sci, 15, 19552-19561

6. Shen L, Su G, Wang X, Du Q, Wang K (2010) Endogenous and exogenous enzymolysis of vegetablesourced glucosinolates and influencing factors. Food Chem, 119, 987-994

7. Yuan G, Wang X, Guo R, Wang Q (2010) Effect of salt stress on phenolic compounds, glucosinolates, myrosinase and antioxidant activity in radish sprouts. Food Chem, 121, 1014-1019

8. Pocasap P, Weerapreeyakul N, Barusrux S (2013) Cancer preventive effect of Thai rat-tailed radish (Raphanus sativus L. var. caudatus Alef). J Funct Foods, 5, 1372-1381

9. Fahey JW, Zalcmann AT, Talalay P (2001) The chemical diversity and distribution of glucosinolates and isothiocyanates among plants. Phytochem, 56, 5-51

10. Dufour V, Stahl M, Baysse C (2015) The antibacterial properties of isothiocyanates. Microbiol, 161, 229-243

11. Ahn ES, Kim JH, Shin DH (1999) Antimicrobial effects of allyl isothiocyanates on several microorganisms. Korean J Food Sci Technol, 31, 206-211

12. Wilson AE, Bergaentzlé $M$, Bindler F, Marchioni E (2013) In vitro efficacies of various isothiocyanates from cruciferous vegetables as antimicrobial agents against foodborne pathogens and spoilage bacteria. Food Control, 30, 318-324

13. Kang BJ (2003) A study on the characteristics of bacteria isolated from cultured flounders (Paralichthys olivaceus) showing disease symptoms in Jeju area of Korea. $\mathrm{Ph} \mathrm{D}$ Thesis. Jeju National University, Korea, p 1-112

14. Choi HS, Kim YC, Lee JS, Jo MR, Seo CH, Park SI (2004) Antibacterial activities of hot-water and ethyl alcohol extracts of medicinal herbs of fish pathogenic bacteria. J Fish Pathol, 17, 39-55

15. Moon YG, Choi KS, Lee KJ, Kim KY, Heo MS (2006) Screening of antioxidative and antibacterial activity from hot water extracts of indigenous plants, Jeju-island. Korean J Biotechnol Bioeng, 21, 164-169

16. Choi HS, Kim JS, Jang DS, Yu YB, Kim YC, Lee JS (2005) Antibacterial activities of Galla rhois extracts against fish pathogenic bacteria. J Fish Pathol, 18, 239-245

17. Kim KH, Kim AR, Cho EJ, Joo SJ, Park JH, Moon JY, Yum JH, Kim TH, Kwon HJ, Lee HT, Kim YM, Lee EW (2014) Antibacterial activity of Rhus javanica against the fish pathogens Vibrio ichthyoenteri and Streptococcus iniae. Korean J Fish Aquat Sci, 47, 018-022

18. Kim SM, Jun LJ, Yeo IK, Jeon YJ, Lee KJ, Jeon HD, Jeong JB (2014) Effects of dietary supplementation with garlic extract on immune responses and diseases resistance of olive flounder, Paralichthys olivaceus. J Fish Pathol, 27, 35-45

19. Kim JW, Kim MB, Lim SB (2015) Formation and stabilization of raphasatin and sulforaphene from radish roots by endogenous enzymolysis. Prev Nutr Food Sci, 20, 119-125

20. CLSI (2012) Methods for dilution antimicrobial susceptibility tests for bacteria that grow aerobically; Approved Standard. 9th ed, Document M07-A9, Clinical and Laboratory Standards Institute, Wayne PA, $1-63$

21. Kim MS, Cho JY, Seo JS, Jung SH, Choi HS, Park MA (2012) Distribution of MIC value of antibiotics against Edwardsiella tarda isolated from olive flounder (Paralichthys olivaceus). J Fish Pathol, 25, 181-188

22. Bulfon C, Volpatti D, Galeotti M (2014) In vitro antibacterial activity of plant ethanolic extracts against fish pathogens. J World Aquacult Soc, 45, 545-557

23. Scholl C, Eshelman BD, Barnes DM, Hanlon PR (2011) Raphasatin is a more potent inducer of the detoxification enzymes than its degradation products. J Food Sci, 76, C504-C511

24. Han SM, Lee KG, Park KK (2011) Antimicrobial activiy of honeybee venom against fish pathogenic bacteria. J Fish Pathol, 24, 113-120

25. Kang MA, Lim MB, Kim JH, Ko YH, Lim SB (2010) Integral antioxidative capacity and antimicrobial activity of pressurized liquid extracts from 40 selected plant species. J Korean Soc Food Sci Nutr, 39, 1249-1256 